\title{
THE NERVOUS AND CIRCULATORY SYSTEMS OF A CRETACEOUS CRINOID: PRESERVATION, PALAEOBIOLOGY AND EVOLUTIONARY SIGNIFICANCE
}

\author{
by JAMES SAULSBURY ${ }^{1, *}$ iD and SAMUEL ZAMORA ${ }^{2,3}$ \\ ${ }^{1}$ Museum of Paleontology, \& Department of Earth \& Environmental Sciences, University of Michigan, Ann Arbor, MI 48109, USA; jgsauls@umich.edu \\ ${ }^{2}$ Instituto Geológico y Minero de España, C/Manuel Lasala, 44 - 9 B, 50006, Zaragoza, Spain; s.zamora@igme.es \\ ${ }^{3}$ Departamento Ciencias de la Tierra-IUCA, Facultad de Ciencias, Universidad de Zaragoza, Zaragoza, Spain \\ ${ }^{*}$ Corresponding author
}

Typescript received 24 May 2019; accepted in revised form 22 July 2019

\begin{abstract}
Featherstars, comatulid crinoids that shed their stalk during their ontogeny, are the most species-rich lineage of modern crinoids and the only ones present in shallow water today. Although they are of considerable palaeontological interest as a 'success story' of the Mesozoic Marine Revolution, their fossil record is relatively species-poor and fragmentary. New Spanish fossils of the Cretaceous featherstar Decameros ricordeanus preserve the shape and configuration of nervous and circulatory anatomy in the form of infilled cavities, which we reconstruct from CT scans. The circulatory system of $D$. ricordeanus was relatively extensive and complex, implying a pattern of coelomic fluid flow that is unique among crinoids, and the peripheral parts of the nervous system include linkages both to the circulatory system and to the surface of the body. A phylogenetic analysis (the first to include both living and fossil featherstars and
\end{abstract}

which includes characters from internal anatomy) recovers D. ricordeanus among the lineage of featherstars that includes Himerometroidea, Tropiometra and 'Antedonoidea', among others. D. ricordeanus is larger than almost any modern featherstar, and its elaborate coelomic morphology appears to be a consequence of positive allometry. All featherstars with coelomic diverticula are shown to belong to a single comatulid subclade, and this feature may constitute a synapomorphy of that group. Some preservation of cavities corresponding to soft tissue is probably not exceptional in fossil crinoids, providing an opportunity to study the diversity and evolution of extinct anatomical systems typically only preserved in Lagerstätten.

Key words: palaeobiology, preservation, fossil, evolution, crinoid, nervous system.
DURING the Mesozoic, the rise of the major modern groups of eukaryotic phytoplankton and the concurrent diversification of marine grazers and durophagous predators initiated (or constituted) a broad shift in the structure of marine ecosystems known as the Mesozoic Marine Revolution (MMR). Crinoids have provided an important case study as 'victims' of the MMR: as durophagous predators such as teleost fishes and echinoids became more prevalent in shallow marine ecosystems, these sessile or slow-moving, benthic passive suspension feeders are thought to have been restricted to deep-water settings in which they encountered fewer predators (Meyer \& Macurda 1977; Bottjer \& Jablonski 1988; Oji 1996; Gorzelak et al. 2012). Featherstars, those crinoids in the order Comatulida that shed their stalk during ontogeny and live as stalkless adults, constitute an important exception to this pattern: featherstars today are globally distributed in shallow and deep-water settings, and represent the majority of crinoid diversity (556/665 spp.; Appeltans et al. 2012). Their relative ecological and evolutionary success has long been attributed to the enhanced motility afforded by a stalkless lifestyle: many featherstars change position diurnally, and most groups are able to swim when stimulated by a potential predator, remaining in the water column for as long as several minutes (Purens 2014). That featherstars can persist in shallow water as a result of their increased motility is corroborated by the fact that all living bourgueticrinids (the 2-4 comatulid lineages that probably re-acquired sessility secondarily; Rouse et al. 2013) are found exclusively in deep water.

Despite their centrality to the evolution of the modern crinoid fauna, the evolutionary history of featherstars is obscured by a poor fossil record. Their fossil diversity is under-represented relative to that of stalked crinoids (Purens 2016), possibly because they are most diverse in areas of poor preservation potential, and most fossil 
species are known only from fragmentary material. Furthermore, the systematics of extant featherstars is based in large part on features that do not preserve in most fossil taxa; for example, the arms and pinnules (Clark 1967; Hess \& Messing 2011). Consequently, much remains unknown about the phylogeny and palaeobiology of early featherstars (Hess 2014). Here we describe new, exquisitely-preserved fossil featherstars from the Lower Cretaceous of north-eastern Spain and infer their phylogenetic affinities in the first explicit phylogenetic analysis of both living and fossil featherstars. Surprisingly, these fossils preserve intricate traces of nervous and circulatory anatomy, shedding light on anatomical innovations within this successful clade of marine invertebrates.

\section{MATERIAL AND METHOD}

Specimens of the featherstar Decameros ricordeanus (Decameridae, Comatulida, Crinoidea) were recovered from the Maestrazgo Basin (Teruel, north-east Spain) in loosely-consolidated marls dated to the early Aptian based on ammonite biostratigraphy, and inferred to have been deposited in a low-energy outer ramp setting (BoverArnal et al. 2016). Detailed palaeoecological and stratigraphical information is given by Zamora et al. (2018). Importantly, no other crinoid species were recovered from the same locality. Material studied here includes 6 complete and two fragmentary calyces, 20 articulated arm fragments, 10 articulated cirrus fragments, 200 isolated cirrals, 400 isolated brachials and 20 isolated radials (Fig. 1). Specimens are deposited in the Museo de Ciencias Naturales de la Universidad de Zaragoza under the acronym MPZ. Specimens were prepared using potassium hydroxide $(\mathrm{KOH})$, and later neutralized with hydrochloric acid (10\%). Crinoids disarticulate rapidly upon dying, and the many partially-articulated specimens described here probably died shortly before or during burial. External features of specimens are preserved in fine detail, and details of stereom on the outside of fossils can be visualized with microscopy for some specimens.

Six fossil specimens were scanned using X-ray microcomputed tomography $(\mu \mathrm{CT})$ at the University of Michigan CTEES facility with a Nikon 62 XT H 225ST industrial $\mu \mathrm{CT}$ system using a tungsten reflection target. Fossils were scanned at $95-105 \mathrm{kV}$ and $96-155 \mu \mathrm{A}$, with resolution $8.0-11.8 \mu \mathrm{m}$. 3D images were reconstructed from 2D projections using CT Pro 3D (Nikon Metrology). Scans reveal complex internal morphology visible as relatively high-density infillings of cavities within the crinoid skeleton. These infillings are reddish-black to orange in colour and are suggested to be iron-rich (Fig. 2A, B). In reconstructed CT datasets, they appear as clusters of small $(\sim 20 \mu \mathrm{m})$ grains that may be either restricted to cavities within the skeleton or distributed more uniformly throughout the stereom. Thus, the amount of anatomical information they preserve is variable. The outline of cavities corresponding to coelomic or nervous tissue is preserved in fine detail in two specimens, but in most cases these details are obscured or obliterated. One fossil specimen (MPZ-2019/366) with exceptionally preserved internal features, scanned at $105 \mathrm{kV}$ and $155 \mu \mathrm{A}$ with a resolution of $10.9 \mu \mathrm{m}$, was chosen for further study. 3D surfaces based on reconstructed $\mu \mathrm{CT}$ scans were generated using the medical imaging software Materialise Mimics (Materialise NV, Leuven, Belgium).

The results of a phylogenetically broad $\mu$ CT-based survey of extant crinoids were used for comparison with $D$. ricordeanus (Saulsbury \& Zamora 2019). Many of these specimens were used in assembling a morphological character matrix for phylogenetic inference. We used molecular data and discrete and continuous morphological characters to infer the phylogenetic affinities of $D$. ricordeanus and several other fossil featherstars. Several studies have estimated the phylogeny of extant crinoids using molecular data (Hemery et al. 2013; Rouse et al. 2013; Cohen \& Pisera 2017) but because previous attempts at inferring the phylogeny of living crinoids have disagreed substantially with one another and have not included many of the taxa for which morphological data have been gathered in this study, we estimated the molecular phylogeny of crinoids independently. We inferred the relationships among 158 species of living crinoid in a maximum likelihood framework using two nuclear (18S, 28S) and three mitochondrial genes (16S, cytb and COI). Non-protein-coding sequences (16S, 18S, 28S) were aligned using PRANK (http://wasabiapp.org; Loytynoja \& Goldman 2005); the remaining sequences were aligned using MAFFT (v. 6.717; https://mafft.cbrc.jp/align ment/software). Aligned sequences were concatenated using SequenceMatrix (v. 1.8; http://www.ggvaidya.com/ta xondna). We used RAxML (Stamatakis 2014) to infer phylogeny using separate partitions for each gene and using the $\mathrm{GTR}+\Gamma$ model of molecular evolution. When the resulting tree is pruned to include only those taxa with morphological data available, it is roughly concordant with the maximum likelihood crinoid phylogenies presented by Hemery et al. (2013) and Rouse et al. (2013), sharing most clades with the findings of both studies. This constraint tree is available in Saulsbury \& Zamora (2019).

We used TNT to infer the phylogeny of living and fossil featherstars with morphological data while using the molecular phylogeny as a topological constraint. A matrix of 37 discrete and 24 continuous morphological characters was assembled and scored for 21 living and 6 extinct species of comatulid crinoid. Specimens examined are listed in Saulsbury \& Zamora (2019). All discrete morphological characters were treated as unordered. Several discrete characters used in the morphological matrix were 
FIG. 1. Skeletal morphology of Decameros ricordeanus. A-C, calyces, lateral view: A, MPZ-2019/367; B, MPZ-2019/366; C, MPZ-2018/483; note the allometric changes in calyx shape, which mirror those of Decameros wertheimi. D, MPZ-2019/368, centrodorsal, aboral view showing texturing on surface. E, MPZ-2019/ 369 , centrodorsal, oral view showing coelomic impressions. F, MPZ-2019/ 370 , fragment of centrodorsal and basal plates; note the impressions of coelomic canals on the basals and centrodorsal. G, MPZ-2019/366, calyx, oral view. H-J, arm plates: H, MPZ-2019/371, 5 proximal brachials with proximal pinnulars in place; I, MPZ-2019/372, 10 distal brachials; J, MPZ-2019/373, a single proximal brachial in aboral view showing rugose texture. Scale bar represents $1 \mathrm{~cm}$.

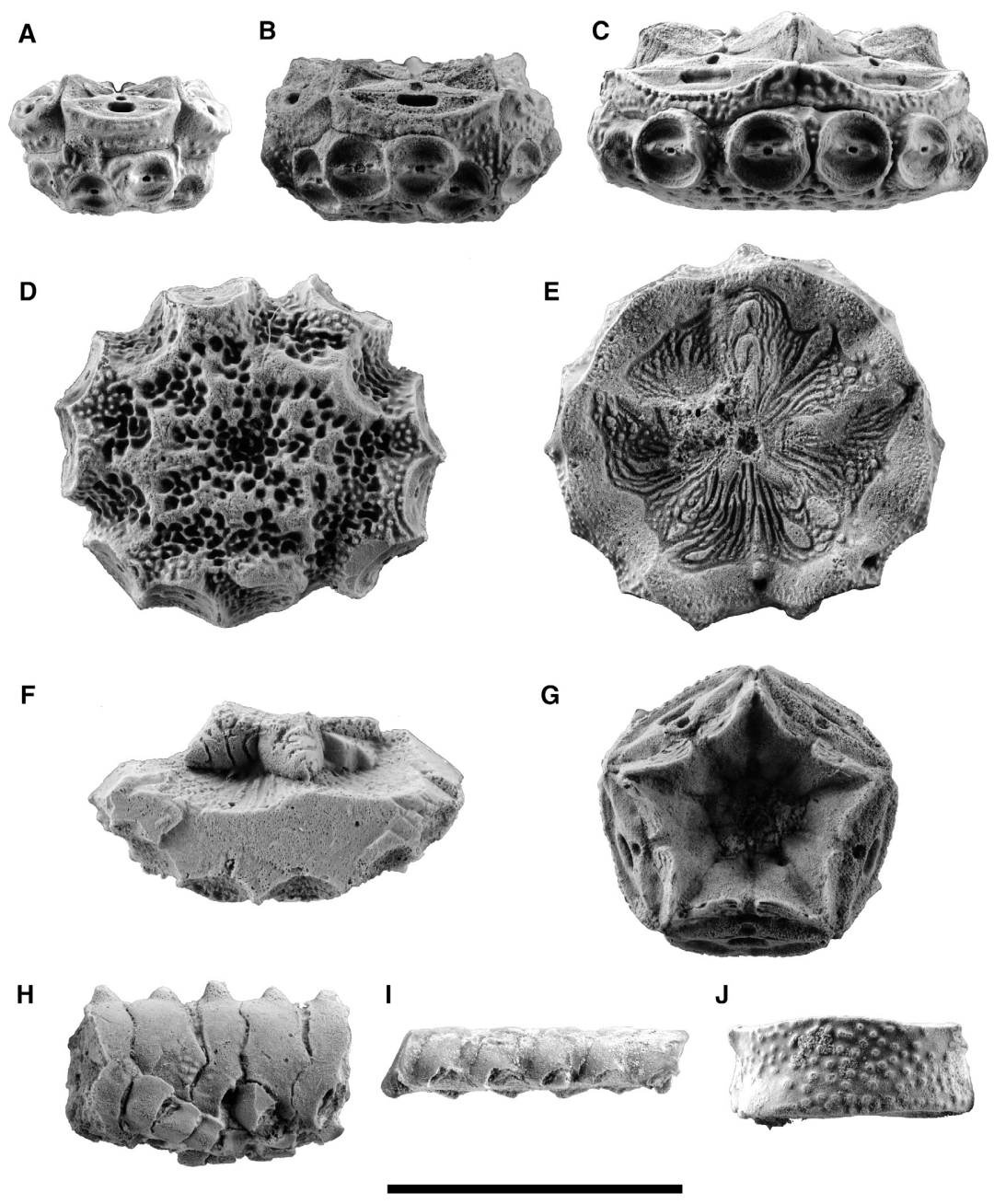

not parsimony-informative, (i.e. they are not scored for at least two states for each of at least two characters) but are included in this study as a framework for future phylogenetic studies. Continuous characters included linear measurements (e.g. centrodorsal radius), ratios of linear measurements (e.g. height of radial muscle fossa/height of interarticular fossa) and one angle measurement (angle between radial interarticular ligament fossa and fulcral ridge). Multiple measurements were averaged where possible, first across repeated elements within specimens and then across multiple specimens within species. Character definitions are provided in Saulsbury \& Zamora (2019, data 2). Measurements were taken from imagery, from 3D models generated from CT scans, or directly from specimens using calipers. We used TNT to infer the phylogeny of featherstars by maximum parsimony with implied weighting. Support was assessed with symmetric resampling (Goloboff et al. 2003), implemented in TNTR (Matzke 2015). We used the paracomatulids (specifically, Paracomatula helvetica) as the outgroup to Comatulida, following Hess (2014). A thorough summary of TNT's treatment of continuous characters is given by Jones \& Butler (2018). The analysis presented here represents the first effort to explicitly infer the phylogenetic affinities of fossil and living featherstars. The molecular sequence alignment, maximum likelihood molecular phylogeny, morphological character matrix, TNT input file and tree file are available in Saulsbury \& Zamora (2019).

\section{RESULTS}

\section{Skeletal morphology}

The material described here is referred to the species Decameros ricordeanus (d'Orbigny in d'Orbigny, 18501852, p. 121), as redescribed by Rasmussen (1961, 1978), based on the following characteristics: arms five, with no syzygies or synarthries; first pinnule on the first brachial; ventral side of centrodorsal with radiating coelomic furrows; large, low, discoidal centrodorsal; large, stout, rhombic basals; wide, shallow radial cavity; and radials 


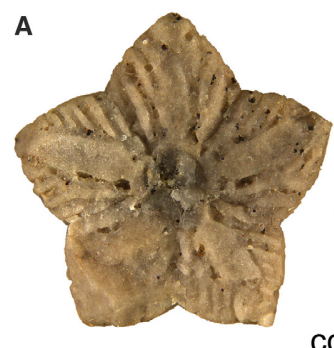

B
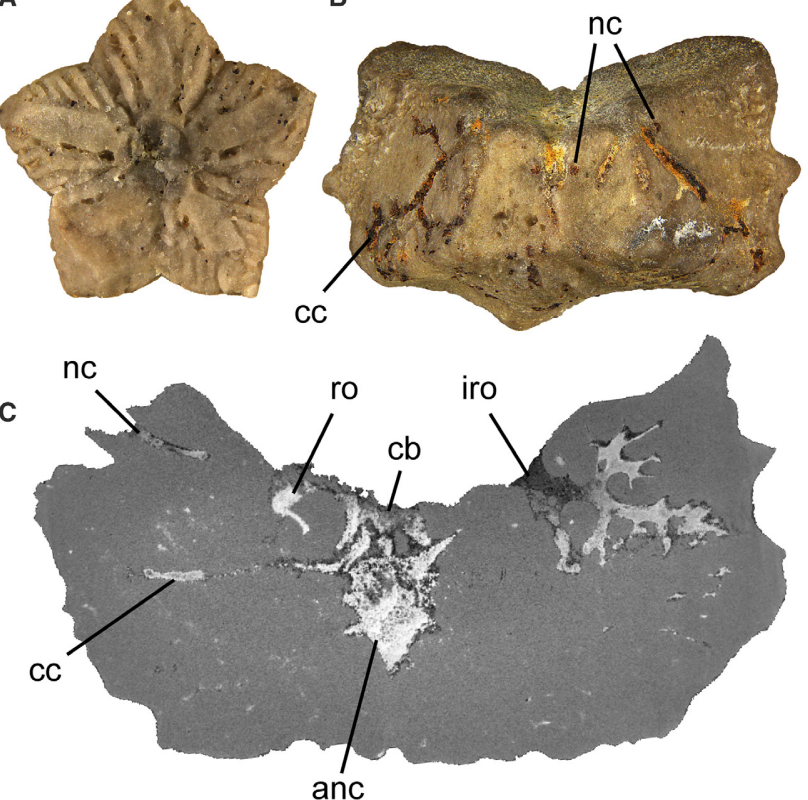

D

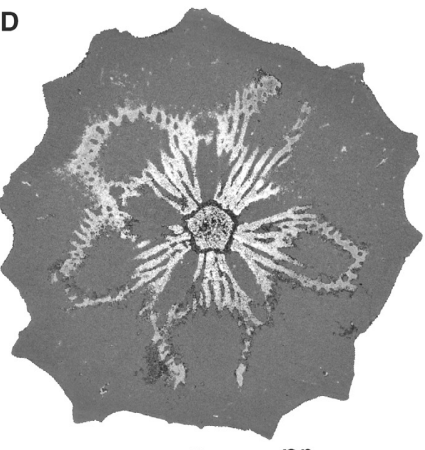

F

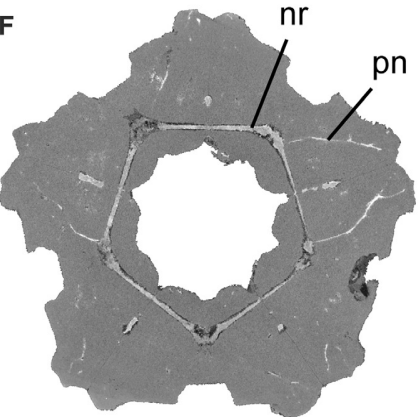

E

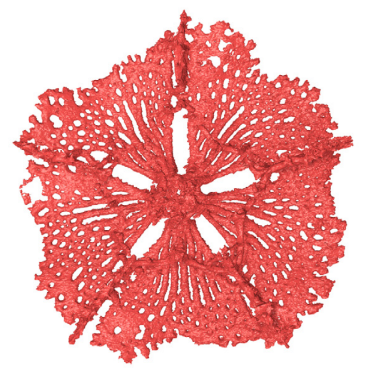

。

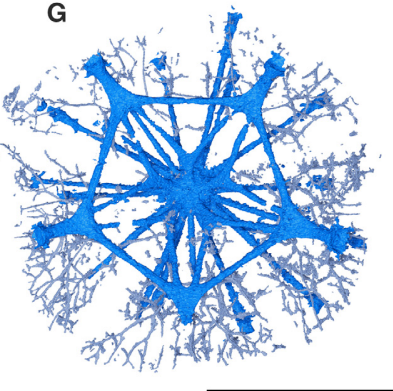

H
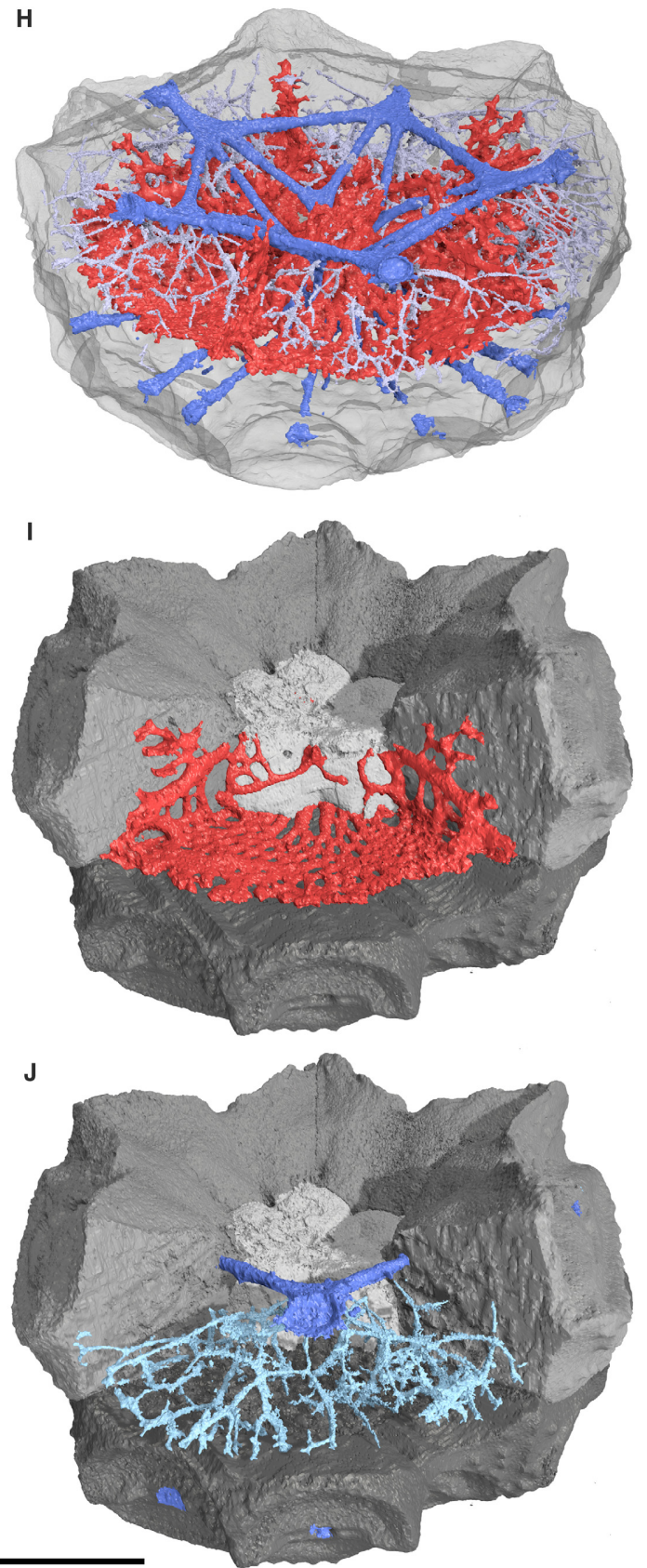

FIG. 2. Skeletal, coelomic, and nervous anatomy of Decameros ricordeanus. A, microphotograph of MPZ-2019/374, basal ring, aboral view; note radially-oriented impressions of coelomic canals. B, microphotograph of MPZ-2019/375, radial plate, interior view; internal anatomy preserved as reddish, granular infillings. C-J, MPZ-2019/366: C, 2D slice through calyx parallel to oral-aboral axis, radius at left and interradius at right; generated from $\mu \mathrm{CT}$ scan; lighter grey values correspond to higher density; D, 2D slice perpendicular to oral-aboral axis showing lateral coelomic diverticula; E, 3D model of coelomic anatomy, oral view; F, 2D slice perpendicular to oral-aboral axis showing pentagonal nerve ring, which gives rise to branches of the peripheral nervous system; G, 3D model of central (dark blue) and peripheral (light blue) nervous anatomy; H, oblique view of coelomic and nervous anatomy; skeleton transparent, other colour codings as in E and G; I, calyx with one radial plate removed, showing nervous anatomy present in a single radial plate; basal plates light grey, radial plates grey, centrodorsal plate dark grey; J, the same view as I, showing coelomic anatomy. Abbreviations: anc, aboral nerve centre; cb, central bundle; cc, coelomic canals; nc, nerve canal; nr, nerve ring; pn, peripheral nerve; ro/iro, radial/interradial openings into coelomic vasculature in the calyx. Scale bar represents: $6 \mathrm{~mm}(\mathrm{~A}, \mathrm{~B}) ; 5 \mathrm{~mm}$ $(\mathrm{C}, \mathrm{H}-\mathrm{J}) ; 9 \mathrm{~mm}(\mathrm{D}-\mathrm{G})$. 
with low free surface (Fig. 1). We note that the proximal dozen or so brachials typically bear a single aboral spine (except the first brachial, which never bears a spine); some brachials have two spines. Decameros ricordeanus is an exceptionally large featherstar, and the material described here includes calyces above $1.5 \mathrm{~cm}$ in diameter. Complete calyces vary in diameter by more than a factor of two, and the ontogenetic changes in shape recorded in these fossils are similar to those observed in its congener Decameros wertheimi (Peck \& Watkins, 1972): larger forms have wider centrodorsals.

\section{Coelomic and nervous anatomy}

Background on the structure and variation of anatomical systems in crinoids is given in Saulsbury \& Zamora (2019). Importantly, all discussion of coelomic anatomy here refers to the somatocoel, the system of spacious, fluid-filled secondary body cavities common to Echinodermata. We do not refer to the haemal or water vascular systems; the former is a relatively inconspicuous primary body cavity (i.e. not a coelom) and neither of the two is associated with the skeleton in any modern crinoid studied (Heinzeller \& Welsch 1994). Like other crinoids, Decameros possesses an aboral extension of the somatocoel in the radial cavity termed the 'axial sinus' (Heinzeller \& Welsch 1994), separated from the aboral nerve centre (Fig. 2C, anc) by the basal circlet. In Decameros this coelomic feature is uniquely elaborate and extensive. Skeletal canals corresponding to extensions of the somatocoel occur along all sutures between plates of the calyx (Figs 1E-F, 2C-D). Canals are circular to elliptical in cross section and are between 0.05 and $0.35 \mathrm{~mm}$ in diameter, usually between 0.15 and $0.3 \mathrm{~mm}$. A single bundle of coelomic canals occurs in the axis of the crinoid, in the centre of the basal ring (Fig. 2C, cb). In each radius, some of these canals connect with a fan-shaped complex of coelomic canals between the radial and centrodorsal plates (Fig. 2I). The canals that make up these fans are radially-oriented and reticulate extensively toward the edges, where they form a perforate sheet (Fig. 2E). Each fan is aborally embayed in the radius, conforming to the suture between the radial circlet and the centrodorsal. Fans do not reach the edge of the calyx, terminating $0.5-1 \mathrm{~mm}$ from the lateral margin. Each fan is connected to a planar network of canals between the radials and basals, and to two such networks between adjacent radials (Fig. 2I). Networks between adjacent radials have a characteristic geometry, their most conspicuous feature being a broad, straight canal connecting the radial fans with the canals between radials and basals. This canal is visible on the surface of disarticulated radials as a diagonal groove (Fig. 2B). The entire network of coelomic canals in the calyx has 11 outlets in the radial cavity.
One large outlet occurs in the axis, corresponding to the large axial bundle of canals mentioned earlier, and 10 outlets (5 radial: Fig. 2C, ro; 5 interradial: Fig. 2C, iro) occur at the junctions between the radial and basal circlets.

Although the calyx coelom in D. ricordeanus is more elaborate than that of any living form, Decameros is not the only crinoid whose coelom bears extensions in the calyx, referred to here and elsewhere (Hess \& Messing 2011; Saulsbury 2019) as coelomic diverticula. Diverticula can be oriented laterally or aborally, corresponding respectively to the 'coelomic furrows' and 'radial pits' mentioned frequently in the taxonomic literature (Rasmussen 1961; Hess \& Messing 2011). Skeletal features corresponding to coelomic diverticula are reported in some or all members of 12 out of 29 comatulid families (Antedonidae, Aporometridae, Asterometridae, Colobometridae, Decameridae, Himerometridae, Mariametridae, Notocrinidae, Ptilometridae, Solanocrinitidae, Tropiometridae and Zygometridae) (Hess \& Messing 2011). Moreover, unique configurations of coelomic morphology appear to characterize major clades. We highlight the following axes of morphological variation, which are incorporated into our phylogenetic analysis:

1. In all himerometroids surveyed here, the coelom in the calyx axis is divided into a central bundle of canals and five radiolateral canals. In all other taxa, the coelom in the axis is present as a single bundle of canals.

2. Notocrinidae and Asterometridae share deep aboral diverticula, but in notocrinids each diverticulum is single. In asterometrids they are divided into a tight bundle of narrow canals.

3. All members of Ptilometridae and Asterometridae, which have been recovered together as a monophyletic clade in previous phylogenetic analyses, share both radial and interradial sets of coelomic diverticula, instead of just the radial ones present in other taxa.

4. In two antedonids surveyed, Heliometra glacialis and Florometra serratissima (the latter not included in the phylogenetic analysis), radial coelomic diverticula are present and are oriented into the radial plate, rather than between the radial circlet and centrodorsal. In our molecular phylogeny and that of Hemery et al. (2013), $H$. glacialis and F. serratissima are closely related to one another and are nested within a clade of antedonids generally lacking radial coelomic diverticula.

Diverticula have not been reported in stalked crinoids, nor do we observe them in any stalked crinoids surveyed here.

The layout of the featherstar central ANS (here used to refer to the relatively thick brachial nerves, pinnule nerves, cirral nerves, pentagonal nerve ring, aboral nerve centre, and the nerves connecting the previous two elements) has previously been reconstructed from CT scans and histology of living species (Aschauer et al. 2010; Engle 2012) 


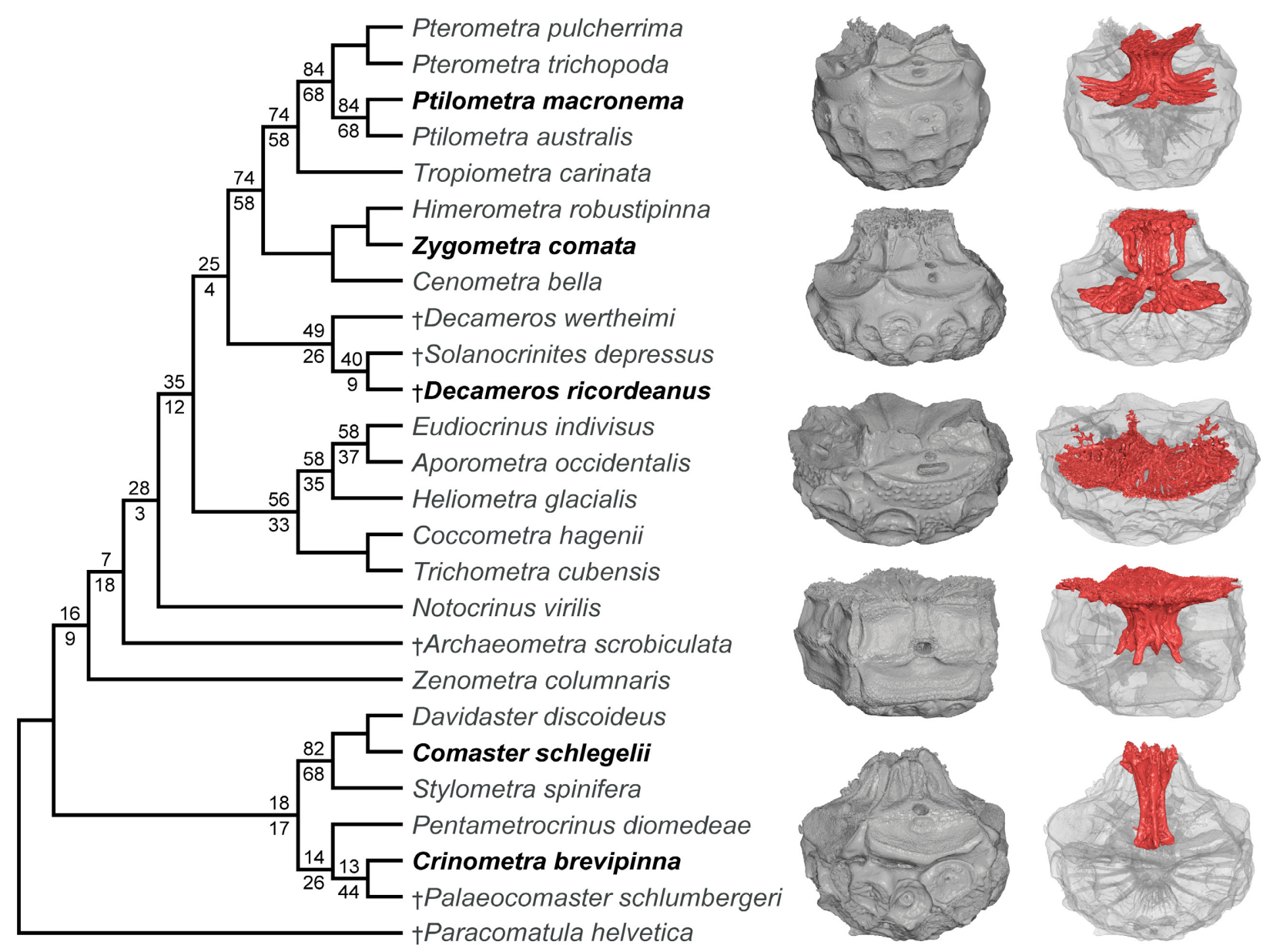

FIG. 3. Phylogeny of living and fossil featherstars. Percentage of replicates in which each clade occurs and group present-contradicted percent differences under symmetric resampling (Goloboff et al. 2003) are plotted above and below each branch, respectively, except for clades recovered in all replicates. Decameros and Solanocrinites are members of an as-yet unnamed clade that includes Notocrinus, Antedonidae, most Tropiometroidea, and Himerometroidea, and which is recovered in all recent molecular phylogenic analyses. 3D models of calyces (left) and coelomic cavities (right) shown for taxa with names in bold font. $\dagger$ indicates extinct taxa. Scale differs between taxa. Colour online.

and appears to be conserved across featherstars. The layout of the central ANS in D. ricordeanus matches previous descriptions given for a generalized featherstar (Moore \& Teichert 1978; Heinzeller 1998), differing only in the relative lengths and diameters of its constituent nerves. Here we reconstruct details of the peripheral ANS, which has received far less study across Crinoidea, in $D$. ricordeanus. Hamann (1889) demonstrated that four pairs of nerves issue from the brachial nerve cord in each arm plate of a living crinoid. Only some or occasionally none of these peripheral nerves are visible in CT scans; it is not clear whether this apparent absence reflects an actual lack of these nerves in some lineages or in some parts of the arm, or whether instead these nerves are present but do not appear because they are finer than the resolution of the CT scan or of the meshwork of the skeleton. In the arm plates (brachials) of several extant featherstars, we observe aborally-directed passages that match the two pairs of putatively sensory nerves indicated by Hamann (1889). We identify this same set of peripheral nerves in D. ricordeanus. More strikingly, CT scans reveal peripheral nerves in the radial plates of extant and fossil crinoids, which previously have not been demonstrated. In several extant crinoids surveyed, one to two pairs of peripheral nerves issue from the brachial nerve in the radial (Saulsbury \& Zamora 2019, fig. S1). In some cases these peripheral nerves terminate on the free surface of the radial (i.e. on the outside of the animal) and in other cases they are directed orally, possibly connecting with one of the other major nervous systems. In Decameros, we identify two pairs of peripheral nerves that originate at the junction of the pentagonal nerve ring with the brachial nerve and another that originates partway along the brachial nerve (Fig. 2F, J). One of the former pair connects aborally with 
a coelomic fan; the other two pairs extend to the free surface of the radial and terminate there. These three pairs of peripheral nerves are extensively linked with each other, such that the peripheral ANS within each radial forms a well-connected network (Fig. 2G, J). The nerves constituting this network are relatively fine: in the best preserved specimen, the brachial nerves in the radials are between 0.35 and $0.4 \mathrm{~mm}$ in diameter and the peripheral nerves are between 0.05 and $0.15 \mathrm{~mm}$ in diameter. We observe a similar, though less well-preserved, network of canals in the centrodorsal plate. We do not observe any peripheral nerves extending between the ANS and the coelom in CT scans of living taxa but because the stereom between the ANS and the coelom is very coarse in places, the existence of such nerves cannot be ruled out.

\section{Phylogenetic affinities}

The results of our phylogenetic analysis are shown in Figure 3. All five fossil species analysed, besides the outgroup, fall within crown-group Comatulida. Solanocrinites depressus, Decameros ricordeanus and D. wertheimi were recovered as a monophyletic clade. This tree topology accords with Rasmussen's (1961) classification of Decameros as a subgenus of Solanocrinites and goes against more recent definitions of the Decameridae and Solanocrinitidae. Decameros and Solanocrinites are recovered as part of a clade comprising Himerometroidea, Tropiometra and Asterometridae + Ptilometridae. Thus, D. ricordeanus is part of a clade whose members generally bear coelomic diverticula. Palaeocomaster and Archaeometra fall outside this clade, despite being previously classified together with Solanocrinites and Decameros in the Solanocrinitoidea (Hess \& Messing 2011). Support values are generally low throughout the tree, but the placement of $D$. ricordeanus is relatively stable even when all morphological characters relating to coelomic diverticula are excluded, when the morphological matrix includes only discrete or only continuous characters, and when all other extinct taxa are removed from the analysis (Saulsbury \& Zamora 2019).

\section{DISCUSSION}

\section{Preservation}

The fine detail of the anatomical features preserved in D. ricordeanus is unprecedented for fossilized post-Palaeozoic crinoids, but the preservation of internal anatomy in fossil crinoids is probably not exceptional. The fossils described here, for example, do not come from a Lagerstätte and are partly disarticulated. Small cavities in echinoderm fossils tend to be obliterated during diagenesis, but the infillings documented here appear to prevent obliteration of internal features. Features preserved in this way should be more amenable to study with $\mu \mathrm{CT}$ if they are infilled with material of a sufficiently different density from the surrounding calcite, as in the fossils presented here. Although D. ricordeanus represents only the third fossil crinoid species studied with $\mu \mathrm{CT}$ to date to our knowledge (Zamora et al. 2015; Baumiller \& Fordyce 2018), reports of internal anatomy in fossil crinoids are fairly common (Jaekel 1891; Rasmussen 1961; Haugh 1975a, b; Hunter et al. 2016), and thus computed tomography has the potential to play an important role in understanding the evolution of organ systems in this taxon. Moreover, a deeper understanding of crinoid internal anatomy and its diversity could help to resolve the uncertain state of postPalaeozoic crinoid systematics. Efforts to infer the phylogeny of extant crinoids within the last decade have disagreed on the relationships between the four living orders, and the phylogenetic affinities of most of the extinct postPalaeozoic groups (including roveacrinids, uintacrinids, the enormous driftwood crinoids Traumatocrinus and Seirocrinus, and millericrinids) remain unresolved. The internal anatomy of fossil crinoids represents a largely untapped source of morphological data, which might prove useful in resolving these uncertainties. At least six unique configurations of the aboral nervous system have been demonstrated in extant crinoids (Heinzeller 1998; Bohn \& Heinzeller 1999), and the results of the present study demonstrate remarkable morphological disparity in the crinoid body cavity, at least among featherstars. Thus, future efforts at understanding the evolutionary history and systematics of fossil Articulata can benefit from a consideration of both external and internal morphology.

\section{Circulation of coelomic fluid in Decameros and other crinoids}

Although the hydrodynamics of circulation in the crinoid calyx have not been studied in detail, it is possible to reconstruct possible circulatory patterns in the coelom of extinct crinoids based on comparison with modern forms. Based on the coelomic layout of the extant featherstar Tropiometra carinata (Saulsbury \& Zamora 2019, fig. S1), the coelomic canals form an axial bundle in the calyx, with incurrent canals fully encircled by excurrent ones. In T. carinata, which bears diverticula, coelomic fluid probably travels down the axis through a central bundle of canals, flushes into the diverticula, and then travels orally through five lateral canals and into the arms. Based on this general pattern we reconstruct one possible circulatory configuration for D. ricordeanus in which coelomic fluid entered the calyx through the central bundle of coelomic canals and flowed out through the ten outlets at the junction between the 
basal and radial circlets (Fig. 2C, ro, iro). Other configurations are plausible; we reconstruct a possible flow pattern here only to show that, despite its complex shape, fluid probably circulated through the entire calyx coelom in life.

Coelomic circulation in crinoids probably serves multiple important roles, including nutrient and hormone transport, and respiration (Grimmer \& Holland 1979). Moreover, the crinoid coelom within the calyx scales with positive allometry, such that all featherstars above a certain size bear coelomic diverticula (Saulsbury 2019). Under isometric scaling, the surface area exposed to circulatory fluid and hence the maximum functional capability of the circulatory system would decrease with increased size, so if a larger crinoid does not have a circulatory system of correspondingly greater surface area, it risks suffocation. Thus, $D$. ricordeanus bears exceptionally complex coelomic diverticula because it is exceptionally large, and having an elaborate circulatory system is necessary at that size.

\section{Neurobiology of Decameros and other crinoids}

The function of the crinoid aboral nervous system (ANS) has been investigated by Hamann (1889) and Nakano et al. (2004). The peripheral parts of the ANS have not yet been investigated in any detail, but some functions can be suggested based on morphology. In each arm plate of living crinoids, two pairs of peripheral nerves are oriented from the brachial nerve toward the aboral surface of the arm, where they terminate. Along the way they do not contact or pass near any effectors like muscles, and Hamann (1889) suggested that these nerves are probably sensory, based on their arrangement. Although the peripheral nerves originating in the radial plates have not been documented previously, their similarity (in terms of symmetry, size relative to the central ANS, and branching geometry) to the peripheral nerves in the arm plates suggests they might play a similar role. Some of the peripheral nerves in the radial circlet terminate on the free surface of the radial in both living crinoids and in D. ricordeanus. These peripheral nerves are well-situated to sense environmental conditions. For example, crinoids are sensitive to flow conditions, and will change their position and deploy or enroll their filtration fans in response to changes in current (Meyer 1997). Nerve endings on the aboral surface of the arms and radials are therefore ideally placed to detect such changes, although such a function is speculative. In Decameros, we also observed peripheral nerves that terminate on coelomic diverticula; we have not identified these in any extant crinoids but cannot rule out their existence. We suggest that, like some other peripheral nerves, these might serve a sensory function, for example by detecting changes in the composition of coelomic fluid. However, we cannot rule out the possibility that these peripheral nerves innervate some previously undetected effector; for example, a feature of endocrine anatomy adjacent to the coelomic canals. No distinct anatomical features have been observed in the dense stereom between the radial plates and the centrodorsal, but little histological work has been done on the crinoid calyx, perhaps due to the difficulties of applying traditional histological techniques to the echinoderm skeleton (Dietrich \& Fontaine 1975). Modern immunostaining approaches have recently been used to reconstruct the nervous anatomy of non-crinoid echinoderms in stunning detail (Schmidt-Rhaesa et al. 2015; Vázquez-Figueroa et al. 2016; Zueva et al. 2018), facilitating robust tests of functional hypotheses. Until modern methods like these are applied to the crinoid nervous system, the functions of the peripheral ANS will remain enigmatic. Nevertheless, it is clear at least that peripheral nerves associated with the circulatory system either originated or became more intricate in the lineage leading to $D$. ricordeanus. Whether and how this is associated with the increase in body size and the associated increase in the complexity of the circulatory system will require comparative analyses and a more complete knowledge of the diversity of the crinoid nervous system.

\section{Decameros in crinoid phylogeny}

The phylogenetic affinities of fossil comatulids inferred in this study are concordant with historical taxonomic work in some but not all respects. Solanocrinites and Decameros are recovered as sister taxa in our analysis; likewise, Rasmussen (1961) considered Decameros to be a subgenus of Solanocrinites, although he later separated them into different families (Rasmussen 1978). However, all fossil featherstars included in our phylogenetic analysis have been assigned to the superfamily Solanocrinitoidea, which our study indicates is polyphyletic. We suggest that the traits that have been used to define this superfamily (including stout basal plates and a narrow centrodorsal cavity) are plesiomorphic or homoplasious. The clade uniting D. ricordeanus and Solanocrinites depressus is recovered with strong support as sister to Tropiometra, a nearly pantropical genus in the monotypic family Tropiometridae. Monophyly of this clade is indicated primarily by continuous characters, including a relatively low centrodorsal, low radials, and a broad radial cavity.

The soft tissue features preserved in D. ricordeanus provide some useful characters for phylogenetic analysis. We recover D. ricordeanus deeply nested within an as-yet unnamed clade that has nevertheless been recovered in all recent molecular phylogenetic studies: namely, the clade that unites Zenometridae, 'Antedonidae', Himerometroidea, most of 'Tropiometroidea' and Notocrinus to the exclusion of Comatulidae, Thalassometridae, Charitometridae, Pentametrocrinidae, and most stalked comatulids. 
Coelomic diverticula are present in most members of this clade that are included in our analysis and are rare or totally absent outside of this clade. Other traits relating to coelomic anatomy help to refine the placement of $D$. ricordeanus. A distinct separation of the axial and lateral coelomic canals in the radial circlet unites Himerometroidea to the exclusion of all other taxa considered, and Decameros is distinguished from members of the Asterometridae by the presence of both radial and interradial coelomic diverticula in the latter taxon. The central ANS exhibits considerable variability among major crinoid taxa, encompassing at least six unique configurations (Heinzeller 1998; Bohn \& Heinzeller 1999). However, featherstars share an apparently uniform central ANS, so no phylogenetically useful characters were sourced from this part of the body. We observe hints of phylogenetically informative morphological variability in the peripheral ANS: for example, CT scans of some extant members of the Comatulidae reveal pairs of thin nerves that extend orally from the brachial nerve in the radial, and we do not observe these in any other taxon. However, it is impossible to conclusively demonstrate the absence of peripheral nerves from CT scans alone, as these nerves may be smaller than the 'resolution' of stereom. A thorough study of the evolution of the peripheral ANS in crinoids will rely on histological research outside the scope of the present study. However, if the success of 'neurophylogeny' for making sense of deep relationships among living and fossil arthropods is any indication (Harzsch 2006; Tanaka et al. 2013; Cong et al. 2014), an understanding of neurobiology may be a useful tool in confronting longstanding problems in crinoid systematics; for example, the relationships among the four extant orders (Hemery et al. 2013; Rouse et al. 2013).

\section{CONCLUSIONS}

The potential for crinoids to preserve phylogenetically useful and biologically interesting features of soft tissue in non-Lagerstätte settings is arguably underappreciated. In many crinoid taxa, including all members of the crowngroup, the skeleton conforms closely to soft-tissue internal anatomy, so the contours of features such as the aboral nervous system and the coelomic circulatory system can be visualized in fossils in which post-mortem cementation or infilling of stereom has not been so extensive as to obscure internal features. Notably, infilling with sediment of a density that contrasts with that of stereom may preserve internal features in great detail, as it does here. The openings of nerve canals are present on most fossil crinoid ossicles (Hess \& Messing 2011), suggesting that some preserve nervous anatomy internally. Findings from sectioned or corroded specimens bear this out (Paul 1970; Žítt 1973). For example, Jaekel (1891) described a silicified and partially corroded Jurassic cyrtocrinid whose aboral nervous system differs strikingly from the highly derived layouts of its extant relatives Cyathidium and Holopus (Grimmer \& Holland 1990; Heinzeller 1998). Beyond encasing their anatomy in dense skeleton, crinoids exhibit a general tendency to calcify their soft tissues to varying degrees (Hyman 1955; Breimer 1978). In extreme cases this can lead to the preservation of entire suites of internal organs, as in the silicified camerate crinoids of the Burlington Limestone (Haugh $1975 b)$. Both these avenues of preservation are especially amenable to study by computed tomography. Further study is likely to resolve important open questions in crinoid phylogeny and facilitate comparative work on the evolution of organ systems.

In this study we reconstruct aspects of the internal anatomy and physiology of the extinct featherstar D. ricordeanus. We find several features that are novel among crinoids, including a complex circulatory system linked extensively with the aboral nervous system. Featherstar internal anatomy as reconstructed by CT scans provides systematically useful information for a group that has to date eluded morphological phylogenetics. Furthermore, our research highlights unexplored and potentially fruitful avenues for histological and functional morphological research on living crinoids.

Acknowledgements. Many thanks to Mr J. Espílez, who found the locality where the fossil material was recovered. Thanks also to University of Michigan undergraduate student Rebecca To for her help in taking the morphological measurements used here in phylogenetic inference. We appreciate the helpful comments of William Ausich, Przemysław Gorzelak and Sally Thomas on an earlier draft of this paper. This study includes data produced in the CTEES facility at University of Michigan, supported by the Department of Earth \& Environmental Sciences and College of Literature, Science, and the Arts. Funding was provided by the Society of Systematic Biologists Graduate Student Research Award to JS, and by the project 'Aragosaurus: recursos geológicos y paleoambientales' (ref: E18_17R), funded by the Government of Aragón, to SZ.

\section{DATA ARCHIVING STATEMENT}

Supplementary information (including character descriptions, supplementary figure and morphological character descriptions), videos and digital models of the fossil crinoid Decameros ricordeanus and its internal anatomy, a table with specimen information, all files needed to rerun phylogenetic analyses, and several phylogenies are available in the Dryad Digital Repository: https://doi.org/10.5061/dryad.rf7c284.

Editor. George Sevastopulo

\section{REFERENCES}

APPELTANS, W., AHYONG, S. T., ANDERSON, G., ANGEL, M. V., ARTOIS, T., BAILLY, N., BAMBER, R., 
BARBER, A., BARTSCH, I., BERTA, A., BŁAZEWICZPASZKOWYCZ, M., BOCK, P., BOXSHALL, G., BOYKO, C. B., BRANDÃO, S. N., BRAY, R. A., BRUCE, N. L., CAIRNS, S. D., CHAN, T. Y., CHENG, L., COLLiNS, A. G., CRIBB, T., CURINI-GAlletTi, M., DAHDOUH-GUEBAS, F., DAVIE, P. J. F., DAWSON, M. N., DE CLERCK, O., DECOCK, W., DE GRAVE, S., DE VOOGD, N. J., DOMNING, D. P., EMIG, C. C., ERSÉUS, C., ESCHMEYER, W., FAUCHALD, K., FAUTIN, D. G., FEIST, S. W., FRANSEN, C. H. J. M., FURUYA, H., GARCIA-ALVAREZ, O., GERKEN, S., GibSON, D., GitTEnBERGER, A., GOFAS, S., GÓMEZ-DAGLIO, L., GORDON, D. P., GUIRY, M. D., HERNANDEZ, F., HOEKSEMA, B. W., HOPCROFT, R. R., JAUME, D., KIRK, P., KOEDAM, N., KOENEMANN, S., KOLB, J. B., KRISTENSEN, R. M., KROH, A., LAMBERT, G., LAZARUS, D. B., LEMAiTRE, R., LONGSHAW, M., LOWRY, J., MACPHERSON, E., MADIN, L. P., MAH, C., MAPSTONE, G., McLAUGHLIN, P. A., MEES, J., MELAND, K., MESSING, C. G., Mills, C. E., MOLODTSOVA, T. N., MOOI, R., NEUHAUS, B., NG, P. K. L., NIELSEN, C., NORENBURG, J., OPRESKO, D. M., OSAWA, M., PAULAY, G., PERRiN, W., Pilger, J. F., POORE, G. C. B., PUGH, P., READ, G. B., REIMER, J. D., RIUS, M., ROCHA, R. M., SAIZ-SALINAS, J. I., SCARABINO, V., SCHIERWATER, B., SCHMIDT-RHAESA, A., SCHNABEL, K. E., SCHOTTE, M., SCHUCHERT, P., SCHWABE, E., SEGERS, H., SELF-SULLIVAN, C., SHENKAR, N., SIEGEL, V., STERRER, W., STÖHR, S., SWALLA, B., TASKER, M. L., THUESEN, E. V., TIMM, T., TODARO, M. A., TURON, X., TYleR, S., UETZ, P., VAN DER LAND, J., VANHOORNE, B., van OFWEGEN, L. P., van SOEST, R. W. M., VANAVERBEKE, J., WALKER-SMITH, G., WALTER, T. C., WARREN, A., Williams, G. C., Wilson, S. P. and COSTELlO, M. J. 2012. The magnitude of global marine species diversity. Current Biology, 22, 2189-2202.

ASCHAUER, B., HEINZELLER, T. and WEINERT, P. 2010. Almost within grasp: crinoid organs rendered 3-dimensionally. 9-14. In HARRIS, L. G., BOETGER, S. A., WALKER, C. W. and LESSER, M. P. (eds). Echinoderms: Durham. Proceedings of the 12th International Echinoderm Conference. CRC Press.

BAUMILLER, T. K. and FORDYCE, R. E. 2018. Rautangaroa, a new genus of feather star (Echinodermata, Crinoidea) from the Oligocene of New Zealand. Journal of Paleontology, 92 (5), 872-882.

BOHN, J. M. and HEINZELLER, T. 1999. Morphology of the bourgueticrinid and isocrinid aboral nervous system and its possible phylogenetic implications (Echinodermata, Crinoidea). Acta Zoologica, 80, 241-249.

BOTTJER, D. J. and JABLONSKI, D. 1988. Paleoenvironmental patterns in the evolution of post-Paleozoic benthic marine invertebrates. Palaios, 3, 540-560.

BOVER-ARNAL, T., MORENO-BEDMAR, J. A., FRIJIA, G., PASCUAL-CEBRIAN, E. and SALAS, R. 2016. Chronostratigraphy of the Barremian - Early Albian of the Maestrat Basin (E Iberian Peninsula): integrating strontium- isotope stratigraphy and ammonoid biostratigraphy. Newsletters on Stratigraphy, 49, 41-68.

BREIMER, A. 1978. General morphology: recent crinoids. T9T58. In MOORE, R. C. and TEICHERT, C. (eds). Treatise on invertebrate paleontology. Part T. Echinodermata 2. Vol. 1. Geological Society of America \& The University of Kansas Paleontological Institute.

CLARK, A. H. 1967. A monograph of the existing crinoids. Volume 1 - the comatulids. Parts 1-5. Bulletin (United States National Museum), 82, 1-860.

COHEN, B. L. and PISERA, A. 2017. Crinoid phylogeny: new interpretation of the main Permo-Triassic divergence, comparisons with echinoids and brachiopods, and EvoDevo interpretations of major morphological variations. Biological Journal of the Linnean Society, 120, 38-53.

CONG, P., MA, X., HOU, X., EDGECOMBE, G. D. and STRAUSFELD, N. J. 2014. Brain structure resolves the segmental affinity of anomalocaridid appendages. Nature, 513, 538-542.

DIETRICH, H. F. and FONTAINE, A. R. 1975. A decalcification method for ultrastructure of echinoderm tissues. Stain Technology, 50, 351-354.

ENGLE, S. 2012. Ultrastructure and development of the body cavities in Antedon bifida (Pennant, 1777) (Comatulida, Crinoida). Dissertation, Freie Universität Berlin, $174 \mathrm{pp}$. https://d oi.org/10.17169/refubium-8224

GOlOBOFF, P. A., FARRIS, J. S., KÄLlersjÖ, M., OXELMAN, B., RAMÍREZ, M. J. and SZUMIK, C. A. 2003. Improvements to resampling measures of group support. Cladistics, 19, 324-332.

GORZELAK, P., SALAMON, M. A. and BAUMILLER, T. K. 2012. Predator-induced macroevolutionary trends in Mesozoic crinoids. Proceedings of the National Academy of Sciences, 109, 7004-7007.

GRIMMER, J. C. and HOLLAND, N. D. 1979. Haemal and coelomic circulatory systems in the arms and pinnules of Florometra serratissima (Echinodermata: Crinoidea). Zoomorphologie, 94, 93-109.

- 1990. The structure of a sessile, stalkless crinoid (Holopus rangii). Acta Zoologica, 71, 61-67.

HAMANN, O. 1889. II. Die Crinoiden. 59-132. In Beiträge Zur Histologie Der Echinodermen. Vol. 4. G. Fischer, Jena.

HARZSCH, S. 2006. Neurophylogeny: architecture of the nervous system and a fresh view on arthropod phyologeny. Integrative \& Comparative Biology, 46, 162-194.

HAUGH, B. N. 1975a. Nervous systems of Mississippian camerate crinoids. Paleobiology, 1, 261-272.

1975b. Digestive and coelomic systems of Mississippian camerate crinoids. Journal of Paleontology, 49, 472-493.

HEINZELLER, T. 1998. The nervous system of crinoids: survey and taxonomic implications. 169-174. In MOOI, R. and TELFORD, M. J. (eds). Echinoderms: San Francisco. Balkema, Rotterdam.

- and WELSCH, U. 1994. Crinoidea. In HARRISON, F. W. and CHIA, F.-S. (eds). Microscopic anatomy of invertebrates, Vol. 14: Echinodermata, Wiley-Liss.

HEMERY, L. G., ROUX, M., AMEZIANE, N. and ELEAUME, M. 2013. High-resolution crinoid phyletic inter- 
relationships derived from molecular data. Cahiers de Biologie Marine, 54, 511-523.

HESS, H. 2014. Origin and radiation of the comatulids (Crinoidea) in the Jurassic. Swiss Journal of Palaeontology, 133, $23-34$.

- and MESSING, C. G. 2011. Comatulida. T70-T159. In AUSICH, W. I. (ed.) Treatise on invertebrate paleontology. Part T. Echinodermata 2 (Revised). Crinoidea. Vol. 3. The University of Kansas Paleontological Institute.

HUNTER, A. W., LARSON, N. L., LANDMAN, N. H. and OJI, T. 2016. Lakotacrinus brezinai n. gen. n. sp., a new stalked crinoid from cold methane seeps in the Upper Cretaceous (Campanian) Pierre Shale, South Dakota, United States. Journal of Paleontology, 90, 506-524.

HYMAN, L. H. 1955. The invertebrates. Vol. IV. Echinodermata. McGraw-Hill.

JAEKEL, O. 1891. Uber Holopocriniden mit besonderer Beruecksichtigung der Stramberger Formen. Zeitschrift der Deutschen Geologischen Gesellschaft, 43, 557-670.

JONES, A. S. and BUTLER, R. J. 2018. A new phylogenetic analysis of Phytosauria (Archosauria: Pseudosuchia) with the application of continuous and geometric morphometric character coding. PeerJ, 6, e5901.

LOYTYNOJA, A. and GOLDMAN, N. 2005. An algorithm for progressive multiple alignment of sequences with insertions. Proceedings of the National Academy of Sciences, 102, 10557-10562.

MATZKE, N. J. 2015. TNTR: R functions to aid analyses in the cladistics program TNT. http://phylo.wikidot.com/tntr [accessed March 2019]

MEYER, D. L. 1997. Reef crinoids as current meters: feeding responses to variable flow. 1127-1130. In LESSIOS, H. A. and MACINTYRE, I. G. (eds). Proceedings of the 8th International Coral Reef Symposium. Vol. 2.

— and MACURDA, D. B. 1977. Adaptive radiation of the comatulid crinoids. Paleobiology, 3, 74-82.

MOORE, R. C. and TEICHERT, C. 1978. Treatise on invertebrate paleontology. Part T. Echinodermata 2. Geological Society of America \& The University of Kansas Paleontological Institute.

NAKANO, H., HIBINO, T., HARA, Y., OJI, T. and AMEMIYA, S. 2004. Regrowth of the stalk of the sea lily, Metacrinus rotundus (Echinodermata: Crinoidea). Journal of Experimental Zoology A, 301, 464-471.

OJI, T. 1996. Is predation intensity reduced with increasing depth? Evidence from the west Atlantic stalked crinoid Endoxocrinus parrae (Gervais) and implications for the Mesozoic Marine Revolution. Paleobiology, 22, 339-351.

ORBIGNY, A. d' 1850-1852. Prodrome de paléontologie stratigraphique universelle des animaux mollusques et rayonnés faisant suite au cours élémentaire de paléontologie et de géologie stratigraphique. Masson. Paris. Vol. 1 (1849 [1850]): 394 pp; Vol. 2 (1850 [1852]): 427 pp; Vol. 3 (1852): 196 pp + table alphabétique et synonymique des genres et des espèces, pp 1-189.

PAUL, C. R. C. 1970. The aboral nervous system of Marsupiocrinus Morris. Fieldiana, 16, 461-469.

PECK, R. E. and WATKINS, W. T. 1972. Comatulid crinoids from the lower Cretaceous of Texas. Journal of Paleontology, 46, 410-414.
PURENS, K. J. S. 2014. Comatulid crinoids in the fossil record: methods and results for the extremely imperfect. $\mathrm{PhD}$ thesis, University of Michigan, $88 \mathrm{pp}$.

— 2016. Detecting comatulid crinoid cryptic species in the fossil record. Palaeogeography, Palaeoclimatology, Palaeoecology, 446, 195-204.

RASMUSSEN, H. W. 1961. A monograph on the Cretaceous Crinoidea. Biologiske Skrifter Udgivet af Det Kongelige Danske Videnskabernes Selskab, 12, 1-428.

— 1978. Articulata. T813-T937. In MOORE, R. C. and TEICHERT, C. (eds). Treatise on invertebrate paleontology: Part T. Echinodermata 2. Vol. 3. Geological Society of America \& The University of Kansas Paleontological Institute.

ROUSE, G. W., JERMIIN, L. S., WILSON, N. G., EECKHAUT, I., LANTERBECQ, D., OJI, T., YOUNG, C. M., BROWNING, T., CisternAS, P., HELGEN, L. E., STUCKEY, M. and MESSING, C. G. 2013. Fixed, free, and fixed: the fickle phylogeny of extant Crinoidea (Echinodermata) and their Permian-Triassic origin. Molecular Phylogenetics \& Evolution, 66, 161-181.

SAULSBURY, J. 2019. Crinoid respiration and the distribution of energetic strategies among marine invertebrates. Biological Journal of the Linnean Society, published online 6 November. https://doi.org/10.1093/biolinnean/blz167

— and ZAMORA, S. 2019. Data from: The nervous and circulatory systems of a Cretaceous crinoid: preservation, paleobiology, and evolutionary significance. Dryad Digital Repository. https://doi.org/10.5061/dryad.rf7c284

SCHMIDT-RHAESA, A., HARZSCH, S. and PURSCHKE, G. 2015. Structure and evolution of invertebrate nervous systems. Oxford University Press.

STAMATAKIS, A. 2014. RAxML version 8: a tool for phylogenetic analysis and post-analysis of large phylogenies. Bioinformatics, 30, 1312-1313.

TANAKA, G., HOU, X., MA, X., EDGECOMBE, G. D. and STRAUSFELD, N. J. 2013. Chelicerate neural ground pattern in a Cambrian great appendage arthropod. Nature, 502, 364-367.

VÁZQUEZ-FIGUEROA， L. D., DÍAZ-BALZAC， R. J., GARCÍA-ARRARÁS, J. E., LÁZARO-PEÑA, M. I. and DÍAZ-BALZAC, C. A. 2016. Holothurian nervous system diversity revealed by neuroanatomical analysis. PLoS One, 11, e0151129.

ZAMORA, S., RAHMAN, I. A. and AUSICH, W. I. 2015. Palaeogeographic implications of a new iocrinid crinoid (Disparida) from the Ordovician (Darriwillian) of Morocco. PeerJ, 3, e1450.

- AUREll, M., VEITCH, M., SAUlsbury, J., LÓPEZ-HORGUE, M. A., FERRATGES, F. A., ARZ, J. A. and BAUMILLER, T. K. 2018. Environmental distribution of post-Palaeozoic crinoids from the Iberian and southPyrenean basins, NE Spain. Acta Palaeontologica Polonica, 63, 779-794.

ŽÍTT, J. 1973. Entoneural system of the Sclerocrinus. Věstnik Ústředniho Ústavu Geologického, 48, 25-29.

ZUEVA, O., KHOURY, M., HEINZELLER, T., MASHANOVA, D. and MASHANOV, V. 2018. The complex simplicity of the brittle star nervous system. Frontiers in Zoology, 15, 194316. 